\title{
独立学院应用型人才培养下《数字电子技术》多维度考试方法改 革研究
}

\author{
王媛 严立甫 \\ 西南科技大学城市学院 \\ DOI:10.32629/er.v2i12.2280
}

[ 摘 要] 独立学院人才培养重心放在应用型工程技术人才培养,更加注重实践与应用能力。而《数字电子技术》作为电类基础课程长期采用期 末笔试、作业、课堂表现等不同权重的形式考核, 即缺乏对数电知识应用的过程管理, 又不能满足应用型人才培养的要求等缺点。多维度考试方 法改革重在细化过程评价,做到“讲练结合”、“知识与实践结合”、“考试与过程结合”。

[关键词] 数字电子技术; 考核; 改革

教育部以关注本科教育、关注人才培养为主题, 提出 “六卓越一拔尖” 计划2.0。 “新时代高教 40 条” 指出, 要想把我国高等教育办好, 并办出世界 一流大学, 人才培养是本, 本科教育是根。为落实科教兴国战略、人才强国 战略, 我国高等教育迎来跨越式发展, 独立院校也称为了高等教育的重要 组成部分。而以人才培养为核心的独立学院培养重心放在应用型工程技 术人才, 更加注重专业实践与应用能力。由于受传统教育的限制, 各类专 业教学考核多采用期末期末笔试、作业、课堂表现等不同权重的形式考 核, 即缺乏对知识应用的过程管理, 又不能满足应用型人才培养的要求 等缺点 ${ }^{[1]}$ 。本文在《数字电子技术》教学改革的实施过程中, 探讨数字电 子技术的课程性质与考核方式, 提出了多维度考试方法改革, 重在细化过 程评价, 受到学生好评并获得良好效果。

\section{1 数字电子技术考试改革目的}

《数字电子技术》是面向电类专业所开设的一门专业基础必修课。通 过课程学习, 让学生掌握数字电子技术方面的基本理论、基础知识和基本 技能, 以及了解常用的数字芯片的使用方法。培养学生分析和解决数字系 统实际问题的能力。为深入学习单片机技术、专用集成电路技术 (ASIC)、 现代数字系统设计 (FPGA) 等有关课程以及为今后从事数字电子技术应用 工作打下良好的基础。

\section{2 数字电子技术传统考核方法}

数字电子技术知识点分布大致为逻辑代数基础、门电路、组合逻辑电 路设计、触发器、时序逻辑电路设计、脉冲波形的产生和整形、存储器和 可编程逻辑器件、数模和模数转换等 ${ }^{[2]}$ 。

在传统考试过程中, 多以选择题、填空题、组合时序逻辑设计、综合 应用题型闭卷考查学生对理论知识的掌握。考试形式单一, 考试内容依附 于教材, 忽略了数字电子技术的综合实践思考, 使的学生存在高分但不能 应用的问题。

\section{3 “多维度” 考核改革理念及实施方案}

3. 1 强调过程的课堂维度考核方式

为深入课堂教学采用 “互联网+课堂” 的形式, 利用 “课堂派” 互动课 堂管理平台, 建立教学课程和教学班级, 学生微信扫描加入课堂, 获取考勤 数据, 教师在PPT中插入互动试题, 讨论题目, 检测学生对知识的掌握情况, 实时统计学生参与互动的数据, 教学资源呈现多样化、课堂形式丰富。利 用 “课堂派” 发布章节自测题, 主要考查知识点的掌握、相关概念的记忆、 发散知识的理解等 ${ }^{[3]}$ 。

3. 2 强调综合设计和应用的实践维度考核
通过实验平台, 完成门电路的逻辑功能与测试、与或非门完成简单组 合逻辑电路的设计、译码器和数据选择器的应用、触发器、计数器工作设 计以及 555 构成施密特、单稳态、多谐振荡器的设计等实验。硬件实验要 求学生课前预习、实验操作、结论分析, 并完成实验报告。

采用EDA技术, 以计算机为平台, 采用Multisim、Proteus等软件仿真, 可以不受元器件种类、不受芯片资源的约束、测试仪器仪表资源的限制, 实现功能仿真等, 为学生自主创新提高平台。极大提升系统设效率, 保证实 验效果。

3. 3强调检验与知识的期末考试维度考核

期末考试采用闭卷考试形式, 重点考查逻辑代数的公式、定理以及逻 辑函数不同表示方法及其相互转换, COMS和TTL集成门电路的逻辑功能和 电气特性, 组合逻辑电路的分析和设计方法、常用中规模组合逻辑器件的 功能、应用及实现方法, 各类触发器的逻辑功能及触发方式, 只读存储器的 种类及特点, 多谐振荡器、施密特触发器、单稳态触发器的功能和应用; 典型 $\mathrm{D} / \mathrm{A}$ 和 $\mathrm{A} / \mathrm{D}$ 转器的基本工作原理、输入量与输出量之间的定量关系、特 点及参数。

3. 4 强调再学习能力的课外设计维度考核

在基本教学要求规定内容下, 拓展和加深理论知识, 开展设计性实验。 主要包括交通信号灯控制逻辑设计、循环彩灯控制电路设计、抢答器设计、 电子幸运转盘电路设计、电子音乐琴设计等, 强调趣味性和使用性。

\section{4 总结}

多维度考核方式的改革避免了考试形式单一、考核内容依附于教材等 缺点, 一定程度上弱化了 “分数” 与 “能力” 不成比例的联系, 而且多维度 的考核形式激发了学生的积极性, 从多方面训练学生的综合能力。在实践 过程中, 学生获取知识的同时也鼓舞了任课教师的不断提升, 以更全面的 知识结构和知识体系完成教学要求。

试验证明, 在《数字电子技术》中采用多维的考核形式, 更适合我校应 用型人才培养模式, 适合在我校乃至其他普通独立院校推广。

\section{[参考文献]}

$[1]$ 韩静, 张福军, 怀保付. 高职学院数字电子技术课程考核方式改革与 实践 [J].科技信息(科学教研),2007(30):241+309.

[2]金金.浅析《数字电子线路组装与测试》课程标准 [J]. 职业技 术,2012(07):52.

[3]刘琨. 基于雨课堂的数字电子技术课程混合式教学研究 [J]. 牡丹江 教育学院学报,2019(02):57-58. 